\title{
PENINGKATAN KESADARAN HUKUM BAGI REMAJA UNTUK MENANGGULANGI PENGARUH GLOBALISASI
}

\author{
${ }^{1)}$ Damianus Agus Sido, Dalintang Ketut Dwi Saputri ${ }^{2)}$, Anita Trisiana ${ }^{3)}$ \\ ${ }^{1,2)}$ Mahasiswa PPKn Universitas Slamet Riyadi Surakarta \\ ${ }^{3)}$ Dosen PPKn Universitas Slamet Riyadi Surakarta
}

\begin{abstract}
ABSTRAK
Indonesia merupakan negara hukum, karena di Indonesia segala sesuatu perbuatan harus didasarkan pada hukum. Tujuan dibentuknya hukum yaitu untuk mendapatkan kepastian hukum. Dengan ini mempunyai tujuan untuk meningkatkan kesadaran akan hukum bagi remaja yang bertujuan untuk menangulanggi pengaruh globalisasi.sebabglobalisasi menyentuh segala aspek dalam kehidupan,dapat menciptakan permasalahan pada remaja. Jadi upaya yang dapat dilakukan dengancara penyuluhan hukum pada remaja, melakukan pembaharuan hukum, proses hukum juga tidak boleh didasarkan pada hal politik, menjujung tinggi hak asasi manusia, penegakan hukum. Hukum di Indonesia belum sepenuhnya dilakukan, salah satu faktor adalah kurangnya kesadaran hukum.
\end{abstract}

Kata Kunci: kesadaran Hukum, globalisasi

\begin{abstract}
Indonesia including as legal state, because in Indonesia all anything must be predicated on law. The purpose of the establishment of law which is to get legal certainty, the purpose here is to increase the legal awarenees for teenagers to overcome the influence of globalization. Because globalization touch all of life so it can also be created the problem in teenagers. So efforts to be made with counseling law in adolescents, update law, legal proccedings should not be based on matters of politics, tipping over high human rights, law enforment. Law in Indonesia has not been fully provided, one of the factors is the lack of legal awareness.
\end{abstract}

Keywords: awareness law, globalization 


\section{PENDAHULUAN}

Hukum begitu sangat identik dengan ketaatan.Sebab dengan ketaatan ditentukan dengan kekuatan dalam sebuah sanksi, dengan seperti itu bahkan sanksi juga tidak dapat menjamin terealisasi tegaknya hukum. Hukum juga merupakan fungsi untuk melindungi kepentingan manusia. Dengan Perkembanagan jaman sekarang yang sangat pesat apalagi dengan perkembangan globalisasi, yang mempunyai banyak pengaruh yang sangat besar.dengan adanya globalisasisekarang dapat memunculkan berbagai permasalahan. Saat ini juga banyak sekali permaslahan yang terjadi terutama pada remaja, dengan adanya globalisasi saat ini banyak pengaruh ketiidak percayaan diri, contoh saja meniru budaya barat bisa dilihat melalui televisi, dan media lainya, yang menjadikan remaja lebih ke meniru , seperti gaya berpakaian, dan juga model potongan rambut.

Peningkatan kesadaran hukum pada saat ini pada remaja sangatlah penting untuk menanggulanggi dampak dari globalisasi saat ini, dengan menjunjung tinggi sebuah kebudayaan bangsaini sendiri, karenakebudayaan merupakan sebuah jati diri bangsa. Dibandingkan dengan Kebudayaan remaja jaman dahulu dengan sekarang sangatlah berbeda, dimana mereka diajari bagaimana bersikap dan bertutur kata dengan baik, contonya saja seperti mencium tangan kepada orang yang lebih tua. Tumbuhnya rasa hormat terhadap orang tua, dan juga menjadikan remaja lebih maju, berfikir dan bertindak secara dewasa dapat membedakan mana yang baik dan mana yang tidak baik. Sedangkan kebudayaan remaja pada zaman sekarang berubah dengan drastic dengan munculnya globalisasi dapat membuat remaja kehilangan kepribadian pada dirinya yang dapat merusak generasi pada masa depan.

\section{METODE}

Pendekatan ini menggunakan sebuah pendekatan kualitatif deskriptif, yang dimana datanya diambil dari deskriptif dengan cara mencari tahu, dan penulisan menggnakan metode penulisan keperpustakaan dengan melalui pengumpulan data yang dapat diperoleh melalu buku-buku, artikel, dan dari internet yang berhubungan dengan dampak pengaruh dari globalisasi. Pengumpulan data ini juga melalui studi kepustakaan melalui:

1. Sumber primer, suatu pengetahuan tentang suatu ide, seperti buku, makalah, artikel, dan juga lain-lain.

2. Sumber sekunder

Berisi bahan dari pustaka atau sumber seperti bahanbahan referensi.

\section{PEMBAHASAN}

\section{Kesadaran Hukum}

Kesadaran hukum ini merupakan sebuah kesadaran atau bisa dibilang nilainilai yang terdapat di dalamdiri manusiadan juga dengan hukum yang ada pada diri manusia atau suatu hukum yang diharapkan, Paul Scholten (Saifullah, 2006: 105). Dengan Munculnya sebuah kesadaran hukum ini dapat juga didorong melalui kepatuhan remaja akan hukum. Dengan meningkatkan Kesadaran hukum dapat juga meningkatkan sebuahtoleransi. Dimana di Indonesia ini sebuah kesadaran hukum sangat kurang, banyak tindakan yang sudah melawan hukum. Contoh saja pengaruh globalisasi yang sudah banyak 
dilakukan oleh remaja, pengaruh negative melalui media, dan juga budaya barat.

Dengan juga sekarang adanya tragedi ilmu pengetahuan hukum di Indonesia dari peninggalan ilmu hukum belanda masa lalu. Dengan pengaruh ilmu hukum pada jaman belanda begitu sangat besar dalam sebuah dunia hukum di Indonesia.

Dengan menurunnya sebuah kesadaran hukum ini dapat juga menggakibatkan banyaknya terjadi pelanggaran hukum, dengan menurunnya tingkat kesadaran hukum pada remaja, dapat juga menimbulkan suatu perubahan-perubahan sosial, sebab adanya pengaruh film misalnya film luar, majalah,dan juga budaya seperti pakaian atau adegan-adegan yang tidak baik. Karena kurang tegasnya penegak hukum dalam menghadapi pelanggaran hukum yang marak saat ini yang sering terjadi, kurangnya pengawasan yang dapat menyebabkan menurunnya kesadaran akan hukum.

Pendidikan disini tidak hanya menanamkan pada pengetahuan saja, akan tetapi juga membentuk sikap positif, dalam proses pembelajaran juga diharapkan dapat juga membangkitkan sebuah rasa taat dan juga ikhlas untuk terwujudnya suatu hukum agar dapat berjalan efektif. Kesadaran hukum tidak juga hanya sebagai kewajiban dan taat terhadap undang-undang saja tetapi juga ketentuan yang tidak tertulis. Kesadaran merupakan suatu proses pengkabaran dan juga pengajaran semacam itu sering kali berlanjut dalam suatu proses pendidikan yaitu proses pembangkitan rasa patuh dan juga setia (Suparman:156) dapat disimpulkan juga dalam sebuah pendidikan disini tidak hanya untuk pembelajaran dan pemahaman saja bahkan agar bisa menjadikan lebih baik dan merubah sikap positif, melalui pendidikan juga dapat juga menjadikan taat dan melakukannya dengan ikhlas. Dan disini perlunya kesadaran. Dapat disimpulkan Sadar dapat dibilang adalah tau. Dimana kesadaran bukan saja suatu fenomena sudah tahu, akan tetapi juga kemantaban hati untuk mematuhi sebauh hukum yang ada dan yang masih berlaku.

\section{Globalisasi}

Globalisasi

merupakan

penyempitan dunia secara budaya, Perubahan-perubahan social yang terjadi didalam suatu masyarakat dapat terjadi oleh karena bermacam-macam sebab, sebab-sebab tersebut dapat berasal dari masyarakat itu sendiri maupun dari luar (Soejono soekanto, 2003:112).Globalisasi sebuah proses dimana pengecilan dunia atau menjadikan dunia selayaknya perkampungan kecil. Dan juga menjadi upaya untuk penyatuan masyarakat dunia dari sisi sebuahgaya hidup, dan budaya. Perkembangan globalisasi juga sangat berpengaruh terhadap remaja, bahkan dilakukan dalam kegiatan sehari-hari dengan perkembangan globalisasi sekarang ini sangat mempengaruhi remaja seperti mengikuti budaya barat, sehingga menimbulkan perubahan dan juga permasalahan karena telah hilangnya sebuah budaya asli dan rasa cinta akan budaya nasionalisme pada generasi muda, menurunya juga rasa patriotisme, hilangnya sifat kekeluargaan dan juga menghilangnya sebuah kepercayaan diri dan gaya hidup kebarat-baratan.

Dengan perkembangan globalisasi terutama dalam teknologi yang begitu sabgat canggih dan begitu pesat. Dan juga pengaruh dari kebudayan. Semakin maju kebudayaannya, semakin juga berkembang teknologinya karena teknologi merupakan 
perkembangan dari kebudayaan yang maju dengan begitu pesat (Adib, 2011,p.254) seperti yang marak terjadi sekarang pada remaja yaitu dengan adanya perkembangan globalisasi ini dapat merubah kebudayaan, banyak berubah seperti budaya barat, dengan adanya teknologi ini bisa melalui teletivi, internet, dan lain-lain.dapat meniru dan dapat merubah budaya aslinya. Dan sekarang juga mengabaikan budaya bangsa sendiri. Memang awalnya teknologi diciptakan untuk mempermudah manusia memenuhi segala kebutuhan hidupnya.(Martono, 2012,pp. 208-291). Tetapi teknologi juga dapat menyebabkan perubahan, tekonologi juga dapat merubah suatu pola aktifitas dalam keseharian, dan juga teknologi dapat merubah suatu gaya hidup, remaja yang menggunakan teknologi dengan nakal dengan lihat video yang tidak patut ditonton belum cukup umur, sebenarnya dengan adanya teknologi dapat juga mempermudah dan bahkan banyak kegunaannya akan tetapi banyak sekali remaja malah salah menggunakannya dan memanfaatkannya.

Teknologi juga meperlihatkan fenomena yang ada dalam masyarakat .tekonologi yang cepat berkembang dengan sangat pesat, dari bidang kehidupan manusia. Bahkan sulit untuk memisahkan kehidupan manusia dengan sebuah teknologi, awalnya memang teknologi merupakan bagian dari suatu ilmu tetapi sekarang ini ilmu bergantung dari teknologi (Dwiningrum,2012,p.155).teknologi juga melanda dalam kehidupan ibaratnya saja orang yang betah tinggal disamping kandang ayam, saking asyiknya tidak sadar jikalau teknologi dapat membuat terpinggirnya sebuah kebutuhan . hanya saja imajinasi sesuai dengan apa yang ditayangkan ditelevisi, apalagi remaja sekarang bahkan ada yang belum bisa untuk membedakan nyata atau visual (Amsal Bakhiar, 2012,pp.224-225) remaja bahkan meniru seperti kekerasan dan bahkan berakibat fatal. Bahkan manusia juga benar-benar sudah menjadi budak dari teknologi.

\section{Meningkatkan Kasadaran Hukum}

Meningkatkan sebuah kesadaran hukum tidak perlu dengan tindakan ancaman, dapat juga dilakukan dengan menggetatkan penataan sesuai dengan Undang-Undang, kesadaran hukum juga tidak hanya hukum tertulis saja, ada pula yang masih menganut hukum adat, karna daerah pedalaman belum mengenal dengan adanya hukum tertulis. Penegakan hukum, khusus pemeriksaan suatu perkara pidana dimuka pengadilan, sering kali terjadi halhal yang mengejudkan, sering pula ada perkara yang sesungguhnya sederhana, dalam arti tidak sulitdalam pembuktiannya, tetapi dalam saat pengadilan dinyatakan bebas hakim(Bahruddin Lopa;2001,136). Hukum diciptakan benar-benar hukum yang bersendikan suatu keadilan, merupakan ketertiban, serta jugs manfaat bagi semua warganya, sehingga memancarkan kewibawaan dan juga perlindungan terhadap setiap manusia Meningkatkan kesadaran hukum harus dilakukan sejak dini, agar mempunyai moral dan juga nilai-nilai yang mempunyai jiwa taat akan adanya hukum. remajasanagt sangat begitu penting untuk generasi penerus bangsa Indonesia.jadi kita perlu sekali untuk menumbuhkan nilai-nilai dan moral agar dapat mematuhi kewajiban-kewajiban kepada keluarga, lingkungan bahkan juga bangsa dan Negara. Dengan membekali remaja dengan meningkatkan kesadaran terkaitan dengan hukum. 
Upaya dalam meningkatan sebuah kesadaran hukum pada remaja untuk menanggulangi pengaruh globalisasi dapat dilakukan dengan::

1) Melalui penyuluhan hukum terhadap remaja

2) Melakukan pembaharuan hukum

3) Proses hukum ini juga tidak boleh dilandaskan dengan hal-hal politik

4) Menjunjung tinggi hak asasi manusia

5) Memperbaiki dan Memperkuat institusi pemerintahan yaitu penegak hukum yang sungguhsungguh mengabdi kebenaran, keadilan, dan juga kepastian hukum.

\section{KESIMPULAN DAN SARAN}

\section{KESIMPULAN}

Kesadaran hukum di Indonesia masih sangat rendah cenderung kurang menghargai dan juga mempercayai hukum yang ada, Pengaruh globalisasi ini juga dapat menimbulkan banyak pengaruh dan juga menimbulkan permasalahan bagi budaya bangsa Indonesia, norma-norma dalam bangsa perlahan-lahan juga memudar, globalisasi sebenarnya kadang juga dapat membawa ke dalam dampak positif dan juga bisa ke dampak negative, dampak positif dapat membawa kearah sebuah kesuksesan, pembentukan dan kemajuan bangsa, ada juga dampak negative dapat membawa pengaruh buruk terhadap remaja.dengan proses globalisasi disini kita bisa mendapatkan informasi dengan begitu cepat, membuat kehidupan menjadi lebih baik. Meskipun permasalah saat ini sangat mengawatirkan karena remaja juga generasi penerus bangsa nanti tetapi dengan pengaruh globalisasi ini banyak pengaruh yang menjadikan remaja tidak mempunyai kepercayaan diri, dengan globalisasi juga penyebabnya remaja mengikuti gaya budaya luar dan mengabaikan budaya yang ada dibangsaini, dengan kecangihan teknologi pada saat ini juga pengaruh dari globalisasi ini membuat remaja meniru akan gaya budaya barat bahkan meniru. dengan ini dapat diupayakan Peningkatan kesadaran hukum terhadap remaja, seperti melakukan penyuluhan, proses hukum tidak boleh didasarkan pada politik, menjujung tinggi hak asasi manusia, dan ditegaskan lembaga penegak hukum.

\section{SARAN}

Dengan peningkatan kesadaran
hukum ini harus memperlukan
kemampuan dan juga kemauan dengan
sungguh-sungguh untuk dapat menegakan
suatu hukum sesuai dengan peraturan
perundang-undangan yang berlaku sampai
saat ini, bukan itu saja kepatuhan akan
hukum bukan saja kewajiban tetapi
merupakan kebutuhan dalam
penyelenggaraan pemerintah.nilai-nilai
dan moral tentang kebenaran, keadilan
nilai sosial, di sini juga membutuhkan
aparat penegak hukum lebih tegas dengan
banyaknya permasalahan yang muncul saat
ini yang dihadapi oleh remaja. Dan
perlunya penyuluhan karena banyak
diperdalaman yang belum memahami akan
hukum yang sudah tertulistapi masih
mempercayai hukum budaya di daerahnya.




\section{DAFTAR PUSTAKA}

Adib, Mohammad. (2011). Filsafat Ilmu: onto-logi, epistemology, aksiologi, dan logika ilmu pengetahuan. Yogyakarta: Pustaka Pelajar.

Bachtiar, Amsal. (2012). Filsafat ilmu edisi revisi. Jakarta:Raja Grafindo Persada.

Baharuddin Lopa.2002. “kejahatan korupsi dan penegakan hukum”. Jakarta kompas

Dwiningrum, S.I.A. (2012). Ilmu sosial \& budaya dasar. Yogyakarta: UNY Press.

Dyah Setya Yoga Aguatin.2011. Penurunan Rasa Cinta Budaya dan Nasionalisme Generasi Muda Akibat Globalisasi. Jurnal Sosial Humaniora, Vol 4, No2.

Firdaus.200.Tragedy Of Law Science Indonesia.Jurnal Hukum PMH 126,126-323.

Irawan,p. (2007). Metodologi Penelitian. Modul 1, Pengantar Metode Penelitian, Jakarta, Universitas Terbuka

Martono, Nanang. (2012). Sosiologi perubahan-perubahan sosial: perspektif klasik, modern,postmodern,dan postcolonial. Jakarta: PT.Raja Grafindo Persada.

Saifullah. 2007. Refleksi Sosiologi Hukum . Bandung: PT.Refika Aditama

Soerjono Soekanto, 1983. Faktor -faktor yang mempengaruhi penegakan hukum. Jakarta:PT.Raja Grafindo Persada, Jakarta,1983 